\title{
Export Performance of Linseed and Its Determinant in Ethiopia
}

\author{
Zerihun Bekele \\ Department of Agricultural Economics, Selale University, Ethiopia
}

\begin{abstract}
This empirical study investigates the determinants of linseed export performance of Ethiopia over a period 19832017. The study identified four factors influencing export performance in terms of export earned like GDP, gross capital formation as a ratio of GDP, openness to trade and world price. As a first step unit root analysis was conducted to test the stationarity of the variables. The variables were non stationary at levels but stationary at their first difference. Second co integration test were employed to check the existence of long run relationship between non stationary variables and found that on co integrating relationship exists in the long run. As a last step vector error correction model was employed to describe the dynamic interrelationship between variables both in the short and long run. The results derived from this study suggest that all variables are significantly influencing on the export in the long run. In the long run, GDP and openness to trade are found to have a positive impact whereas; world price and capital formation had a negative impact. In the short run capital formation and world price had significantly influencing export performance whereas: GDP and openness to trade was insignificant
\end{abstract}

Keywords: export, vector error correction model

DOI: $10.7176 / \mathrm{DCS} / 9-12-03$

Publication date: December $31^{\text {st }} 2019$

\section{INTRODUCTION}

International trade is the back bone of global economy brings together a numerous advantages to the trade partnering countries that are becoming rich and wealthy. Economic success in many nations is based on the involvement of a country's in international trade. Resource endowment and level of technology resulted in variation in the production of goods between different nations. The engagement of a nation in international trade depends upon a nation's specializations in the productions of goods. The benefit of specialization and improvement in the efficiency of production is realized through effective international trade participation (Palley, 2011).

Every nation in the world has development objectives and sustainable economic growth is leads to economic development. Export diversification had greater contribution in per capita economic growth (Fugazza, 2004). Export as one of the variable, out of many, to accelerate economic growth and with greater market access can facilitate rapid economic growth. The countries that have sound export performance gradually improve their economic performances. Because export plays a vital role in an economy influencing on the performance of balance of payment, level of employment and economic growth through enhancing aggregate demand (Bhavan,2016).

The export base of many developing nation is highly linked with exporting of primary agricultural commodities that accounts for a largest share of a country's export earnings. Majority of developing countries gain their export earnings from the exports of primary commodities such as agricultural commodities \& foods, fuels and minerals (UNDP, 2017). Similarly in Ethiopia according to Belayneh, 2012, the export sector could be characterized by few dominant traditional agricultural commodities namely coffee, hide and skin, oilseeds and pulses. Coffee alone constitutes more than 50\% of the Ethiopian commodity export. According to WTO, 2017 the share of agricultural export in the world market is still low and only 0.0013 percent in 2016/17.

The relative share and dominance of these major exports have declined, despite the fact that their trade volumes have been increasing in absolute terms (Biggs, 2007).UNCTAD, 2017 labeled Ethiopia as a country of 'strong commodity export dependent' since more than $80 \%$ of total merchandise export value is from exported commodity. Thus export diversification by including nontraditional agricultural product would be valuable. WDI, 2017 also indicated Ethiopia's export share of GDP declined through years between 2011 and 2017 from 16.68\% reaches $7.6 \%$ respectively.

During the last three years, i.e. 2014/15 - 2016/17, average annual export value of the country was approximately 3 billion USD, of which the top export commodities se shares were: coffee (27.1\%), oilseeds (15.2\%), gold $(9.3 \%)$, khat $(9.2 \%)$, pulses $(8.3 \%)$, and cut flowers $(7.4 \%)$. Further breakdown of the oilseed exports indicate that sesame seed has overwhelmingly dominated the subgroup. During the same period, the average annual export value of sesame seed was more than 400 million USD. This is about $10 \%$ of the country's total export value or more than $90 \%$ of the total oilseedse export value. Niger seed, castor seed and linseed in this order are the next top export oilseeds (NBE, 2017).

The major producers of oilseeds in the worlds are USA, China, Brazil, India, Malaysia, Indonesia, EU-15 countries, central Europe, Canada and Argentina (FAO, 2017). Ethiopia ranks among the top five producers of linseeds and sesame in the world next to Canada, China, USA and India and also earned a high export income from oilseed export market after coffee (Hailegiorgis, 2011). Linseed, as a major component of oilseeds, has a 
good export potential earning like sesame and Niger seed. Increasing world demand for oilseeds and specialized product given the available production capacity made oilseed as important export crop (Bennet, 2004). As indicated in FAO data base world major linseed exporter includes Canada, Belgium, UK and USA. In the world market Ethiopia's major linseed trading partners include China, Belgium and Vietnam. The world market for oilseed is dominated by sesame but now a days Linseed is also exported to different world and contribute in export earnings. Thus analysis of determinants of export performance of linseed is important in identifying the possible factors affecting export performance in terms of earnings.

Therefore, the objectives of this study therefore to evaluate the performance of linseed export and its short run and long run determinant in Ethiopia using annual macroeconomic annual time series data of UNCTAD, ERCA, WBDI and FAO from a period of 1983-2017. The study considered limited factors including world price, gross capital formation, GDP and openness to trade. Moreover, Goldstein and Khan (1985) imperfect substitution model were applied. Fundamental assumption underlying the imperfect substitutes model is that neither imports, nor exports can be considered perfect substitutes for the domestic products. Perfect substitutes model, on the other side, assumes perfect substitutability between domestic and foreign goods and is typically used in the case of highly disaggregate data set. Since under the key assumption of the perfect substitutes model each country would be only an exporter or an importer of a traded good but not both, which is not observed in the real world, this model has attracted much less attention in the empirical studies than the imperfect substitutes model. The two models are usually perceived as competitors, but Goldstein and Khan (1985) suggest their possible coexistence: one should be applied in the case of aggregate and the other in the case of highly disaggregates data.

The export performance of an economy depends largely on GDP of a country. This can be argued that the output capacity of an economy is an indication for future supply capacity. Thus an increase in output will improve export earnings. According to Hailegiorgis, 2011 the output of the economy increases the supply capacity and export earnings improved. Increased world price had an effect on export earnings through increased incentive and competitiveness

Openness of trade also had impact on export performance. The relative openness of a country to international trade would increase the export earnings and indicates the integration of a country into the world market. The openness of trade can be approximated by the sum of export and import of goods and service to GDP ratio.

Gross capital formation is an outlay on fixed asset of the economy and net changes in the level of inventories. It is one of the indicators of investment in the domestic economy (Mehrara and Musaai, 2013) usually included investment on infrastructural development. Infrastructure is a key determinant of export performance. In this study capital formation as a ratio of GDP is proxy for quality of infrastructure. Bhavan, 2016 found a negative coefficient of capital formation in the short run and insignificant capital formation coefficient in the long run.

\section{RESEARCH METHODOLOGY}

\section{Model Specification}

The study was based on secondary data sources from different data base sources. Many macro-economic time series variable is expected to influence the export performance of oilseed crops, linseeds. But based on availability of the data selected factors were used for further analysis. Thus, time series data were extracted from FAO stat and World Bank data base. Annual macroeconomic time series were also extracted from different source. The study covers 34 years of data from 1983-2017.

As a first step, Unit root analysis was performed in order to test stationary properties of the variables because variables with non-stationary properties may produce spurious result if regression analysis is employed to test long run elasticities. Therefore, in order to overcome this issue the variables were tested by employing the ADF test method. As a second step, Co-integration Johansen maximum likelihood method was employed to test the long run relationship among the non-stationary variables used in this study. As a third step, the Vector Error Correction Model (VECM) was employed to describe the dynamic interrelationship among the variables. Therefore, the following model is expressed to analyze the determinants of the export performance of Linseed in Ethiopia.

The study identified export performance (value of exported commodity) of linseed in Ethiopia as a function of capital formation, openness of the country, world price and real output of a country. Imperfect substitution model by Goldstein and Khan (1985) were adopted here to express the analysis.

Linseeds export performance $(E X)=f$ (cap, openness, $P w$ and $R G D P)$

The $\log$ transformed function were used for the above equation for estimation and differentiating with respect to time give the variability in export earning as

$$
\log E X t=\beta_{0}+\beta_{1} \log \operatorname{cap}_{t}+\beta_{3} \operatorname{logopeness}_{t}+\beta_{4} \log P w_{t}+\beta_{5} \log G D P_{t}+\varepsilon_{t}
$$

Where: $\log$ EX is the value of exported commodity (export earned at time $t$ ), Log cap is the gross capital formation as a percentage of GDP, Log openness is export plus import as percentage of GDP (a proxy for degree of openness in log form), Log Pw is the price of commodity in the world and Log GDP is GDP of exporting country. $\beta^{\prime} \mathrm{s}$ are the unknown parameter to be estimated, $\mathrm{t}$ is time in years from 1983-2017 and $\varepsilon$ is the random term error that are independently and identically distributed with mean zero and constant variance. The above 
equation is estimated using time series analysis in Eview 10.

\section{RESULT AND DISCUSSION}

The classical linear regression model (CLRM) and VECM (vector error correction model) were used to estimate the data. The estimation begins with the testing of variables for unit root to determine whether they can be considered as a stationary or non-stationary process. Table 1 presents the Augmented Dickey Fuller (ADF) tests of variables. The tests showed that all the variables were non-stationary at level. The variables were stationary at their first difference. Critical values for tests were found to be -1.95 and -2.63 at $5 \%$ and $10 \%$ respectively. Annex Table 1(a-e) gives details of unit root test outputs of variables.

Table 1: ADF unit root test

\begin{tabular}{|l|c|c|c|c|}
\hline Variable & ADF test statistics & $\begin{array}{l}\text { Order of } \\
\text { integration }\end{array}$ & Critical value at 5\% & $\begin{array}{l}\text { Critical value at } \\
1 \%\end{array}$ \\
\hline Log EX & -6.205590 & $\mathrm{I}(1)$ & -1.951687 & -2.639210 \\
\hline Log openness & -7.259492 & $\mathrm{I}(1)$ & -1.951332 & -2.636901 \\
\hline Log PW & -9.777565 & $\mathrm{I}(1)$ & -1.951332 & -2.639210 \\
\hline Log cap & -6.481426 & $\mathrm{I}(1)$ & -1.951332 & -2.636901 \\
\hline Log RGDP & -2.835826 & $\mathrm{I}(1)$ & -1.951332 & -2.636901 \\
\hline
\end{tabular}

The notion behind co integration test assumed if there is a long-run relation-ship between two or more nonstationary variables, deviations from this long-run path are stationary. As all variables are integrated of the same order, the co-integration analysis can be performed to test the long run relationship between the variables. A Johannsen multi variate co integration test was employed to test for possible co integration amid variables. Trace test and Max Eigen criteria used in determining the number of co integrating equation. The maximum Eigen value test starts with the null hypothesis of at most $r$ co-integrating vector against the alternative of $r+1$. The result for maximum Eigen value test confirms the rejection of the null hypothesis; i.e., no co-integrated vectors. Consequently, Max Eigen and trace value statistics indicates one co integrating equation at 5\% significance level. In other words accepting there is one co integrating vector since in both trace and max Eigen criteria test statistic (86.8 and 42.8) is greater than critical value at 5\%(69.8 and 33.8) respectively. Thus we can reject the null of more than one co integrating vector (Table 2). The integrated variables were also examined to check for co integration in the long run.

Table 2 (a): Co-integration test for $\log d v, \log$ cap, $\log$ openness, $\log p w$ and $\log r g d p$ max Eigen criteria

\begin{tabular}{|l|l|l|l|c|}
\hline Hypothesized no.of $(\mathrm{CE})$ & Eigen value & Trace statistic & Critical value at 5\% & Prob** \\
\hline $\mathrm{r}=0^{*}$ & 0.726708 & 86.88316 & 69.81889 & 0.0012 \\
\hline $\mathrm{r} \leq 1$ & 0.548412 & 44.07513 & 47.85613 & 0.1084 \\
\hline $\mathrm{r} \leq 2$ & 0.301251 & 17.84064 & 29.79707 & 0.5779 \\
\hline $\mathrm{r} \leq 3$ & 0.152422 & 6.011341 & 15.49471 & 0.6942 \\
\hline $\mathrm{r} \leq 4$ & 0.016649 & 0.554047 & 3.841466 & 0.4567 \\
\hline
\end{tabular}

Table 2 (b) Max Eigen criteria

\begin{tabular}{|l|l|l|l|l|}
\hline Hypothesized no.of (CE) & Eigen value & Max. Eigen statistic & Critical value at 5\% & Prob** \\
\hline $\mathrm{r}=0 *$ & 0.726708 & 42.80803 & 33.87687 & 0.0033 \\
\hline $\mathrm{r} \leq 1$ & 0.548412 & 26.23449 & 27.58434 & 0.0736 \\
\hline $\mathrm{r} \leq 2$ & 0.301251 & 11.82930 & 21.13162 & 0.5646 \\
\hline $\mathrm{r} \leq 3$ & 0.152422 & 5.457294 & 14.26460 & 0.6834 \\
\hline $\mathrm{r} \leq 4$ & 0.016649 & 0.554047 & 3.841466 & 0.4567 \\
\hline
\end{tabular}

Note: the test assumes linear deterministic trend in the data

Trace test and max Eigen test indicates 1 co integrating equation at the 0.5 level *denotes rejection of the hypothesis at the 0.05 level ** Mackinnon Haug- Michells (1999) p values

Vector error correction model: Vector Error Correction Model is a special case of VAR for variables that are stationary at first difference. Since all endogenous variables are stationary at first difference and found to have a vector of co-integrating equation, VECM is employed to study dynamic relationship between the variables. The required post estimation tests such as LM test for autocorrelation in residuals, test for normally distributed residuals and stability condition of VECM, were performed in order to ensure that the VECM results are reliable.

Table 3: Normalized co integrating coefficient (Standard error in parenthesis)

\begin{tabular}{|l|l|l|l|l|l|}
\hline LOGEX & LOGOPENES & LOGPW & LOGRGDP & LOGCAP & C \\
\hline 1.000000 & $-5.893504^{*}$ & $5.906263^{*}$ & $-5.689132^{*}$ & $6.90322^{*}$ & 40.0665 \\
\hline & $(1.38539)$ & $(0.56496)$ & $(0.57763)$ & $(1.52432)$ & \\
\hline t statistics & 4.254 & 10.4543 & 9.849 & 4.5287 & \\
\hline
\end{tabular}

*significance at $1 \%$ 
The normalized co integration equation also depicted long run coefficients of the model (table 3 ). As indicated above, by changing their sign, log openness and log rgdp are positive determinant of export performance of linseed in the long run while log pw and log cap are negative determinant. All variables are used in the logarithmic form thus; the estimated coefficients can directly be interpreted as long term elasticity.

Since that all determinants incorporated into the model are statistically significant at $1 \%$ level having a long run relationship. Thus, according to Johansen's method by reversing the signs of the coefficients, the model for Ethiopia's linseed export can be specified as follows:

$$
\log E X=-40.066+5.689 \log G D P+5.89 \log O p e n e s s-5.91 \log P w-6.903 \log C a p
$$

GDP and openness are positively related with export performance while negative relation was found between capital formation and world price. The result for impact of GDP of a country is also in accordance with Macroeconomic theories. As the output of the given economy increases more would be supplied to the world market. The coefficient for gross domestic product for the country is 5.68 which mean that a one percent change on real out GDP of country results 5.69 percent increase in export earnings. Similarly Openness as a measure of degree of involvement in international trade had a positive coefficient implied a $1 \%$ increase in openness of trade associated with a $5.89 \%$ increase in export earnings.

World price had negative and significant long term impact on export performance. This could be due to the case that an increase in the world price resulted in increasing the demand for quality product by importing countries which is usually unable to be met by developing countries exporters.

Capital formation as a proxy for government investment in infrastructure had significant negative impact at 1 percent significance level in decreasing export earnings in the long run. A $1 \%$ increase in gross capital formation resulted in a $6.9 \%$ decrease in export earnings. This may be due to capital formation affect the economy in different path other than the export sector

After identifying the co integration equation our lagged residual for error correction term is identified. The equations were also tested for unit root and found to be integrated of order (I) and passes the ADF units root test (Annex Table 5). The final estimation was made after error correction term entered into VECM model (Annex Table 4). The equation identified

$\mathrm{ECT}=\log$ openness $-0.378 \log \mathrm{pw}+0.229 \log \operatorname{rgdp}-0.556 \log$ cap

Table 4: Estimation results Using VECM

\begin{tabular}{|c|c|c|c|c|}
\hline \multicolumn{5}{|c|}{ Dependent Variable: D(LOG EX) } \\
\hline \multicolumn{5}{|c|}{ Method: Least Squares } \\
\hline & Coefficient & Std. Error & t-Statistic & Prob. \\
\hline $\mathrm{ECT}(-1)$ & -0.763015 & 0.206250 & -3.699462 & $0.001 * * *$ \\
\hline $\mathrm{D} \log \mathrm{dv}(-1)$ & 0.009956 & 0.174063 & 0.057196 & 0.9548 \\
\hline $\mathrm{D} \log \operatorname{rgdp}(-1)$ & 4.768950 & 3.360384 & 1.419168 & 0.1677 \\
\hline D $\log$ openness $(-1)$ & -0.886590 & 2.329590 & -0.380578 & 0.7066 \\
\hline $\mathrm{D} \log \mathrm{pw}(-1)$ & 1.977354 & 0.809656 & 2.442217 & $0.0217 * *$ \\
\hline $\mathrm{D} \log \operatorname{cap}(-1)$ & 5.785447 & 2.403833 & 2.406759 & $0.0235 * *$ \\
\hline $\mathrm{C}$ & -0.311384 & 0.191031 & -1.630016 & 0.1152 \\
\hline R-squared & 0.459820 & Mean dependent var & & -0.043507 \\
\hline Adjusted R-squared & 0.335164 & S.D. dependent var & & 1.047010 \\
\hline S.E. of regression & 0.853706 & Akaike info criterion & & 2.707371 \\
\hline Sum squared resid & 18.94914 & Schwarz criterion & & 3.024812 \\
\hline Log likelihood & -37.67161 & Hannan-Quinn criter. & & 2.814180 \\
\hline F-statistic & 3.688689 & Durbin-Watson stat & & 2.014614 \\
\hline Prob(F-statistic) & 0.008742 & & & \\
\hline
\end{tabular}

*** Significant at $1 \%, *$ significant at $5 \%$

The VECM estimates indicated (Table 4) that world price, capital formation and the error correction term is significant and positive at $5 \%$ while the remaining factors are insignificant. The implication for their significance is to emphasize on the importance of this variable in explaining export performance of linseed in the short run. The ECM output indicated the coefficient 1.98 and 5.78 for world price and capital formation respectively show the short run impact of the two variables that cause changes in export earnings of linseed. That is world price and capital formation in the previous year affects current export performance. This is due to the fact that as world price increase, the incentive for domestic producers to produce more would increase similarly which in turn affects the export earnings. Capital formation also make domestic producers product easily available to the world market. The insignificance of GDP and openness of trade imply neither of them had a short run impact on export 
performance. The coefficient of ECT indicates that the speed of adjustment to the long run equilibrium is significant and can be concluded that $76 \%$ of deviation would be eliminated annually.

\section{CONCLUSION}

The objective of this paper of this study was to evaluate the long run and short run impacts of determinants on linseed export performance over a period 1983-2017. The study investigates empirically the trend of export performance by analyzing world price, GDP, gross capital formation and openness to trade. The evidence from this study suggests that capital formation and world price significantly influence linseed export performance. The long run impact on export performance was explained by all the four factors. It was inferred that the short run implication of the significant variable clear that the incentive derived due to the increased world price usually accompanied with a high quality demand for imported commodities to developed world. This quality demand world market has to be satisfied by backup the export sector of the economy. One way of achieving this goal is investment in infrastructural development, facility and fixed asset. In the long run the increment in real out output of the economy and country's engagement in international trade will improve the export performance. Moreover investment on fixed asset capital towards the export sector also had positive impact. Finally other studies that incorporate more factors like foreign direct investment and importing countries variables would be important for further analysis of export performance of linseed.

\section{References}

Bennet, M., 2004. Sesame. In; Salvin. S., M. Bourke and T. Byrne, 2004. The new crop industries handbook. Australian Government, RIRDC publication04/125. P214-220

Biggs,T. (2007). “Assesing Export Supply Constraints: Methodology, Data and Measurement”. AERC Research Project on Export Supply Response Capacity Constraint in Africa, Paper No. ESWP_02

FAO (Food and Agricultural Organization), 2017. Food outlook

Fugzaza. M (2004), “Export Performance and Its Determinates: Supply and Demand Constraints.”, policy issue in International Trade and Commodities Study Series Vol.1 No.26 Geneva, Swaziland

Goldstein, M., and M. Khan. 1985. "Income and Price Effects in Foreign Trade." In R. Jones and P. Kenen, eds., Handbook of International Economics 2. Amsterdam: Elsevier

Hailegiorgis Biramo, 2011. Export performance of oilseed and Its determinant in Ethiopia. American journal of economics 2011:1(1): 1-14

Mehrara M. and Musai M. (2013). The Causality between Capital Formation and Economic Growth in MENA Region. International Letters of Social and Humanistic Sciences, 8, 1-7., 1-7.

National Bank of Ethiopia (NBE) 20016/17, Various Issues.

Palley.T.I (2011). "The Rise and Fall of Export Led Growth". Working Paper 675. Levy Economics Institute of Bard College.

Thangamani Bhavan, 2016:the determinants of export performance :The case of Srilanka. International research journal of social science Vol.5(8),8-13

UNCTAD,(2007). Trade Development Report. United Nation, New York, Geneva

UNDP, (2017). "Manufacturing export Performance" available online at Communication.et@ UNDP.org or WWW.et.undp.org 
ANNEX

Table 1(a): ADF test on $\log \boldsymbol{E} \boldsymbol{X}$, at first difference with no intercept and trend

\begin{tabular}{|c|c|c|c|c|}
\hline ADF test statistics & \multicolumn{3}{|c|}{$\begin{array}{c}\text { Augmented Dickey-Fuller Test Equation } \\
\text { Dependent Variable: D(LOGEX,2) } \\
\text { Method: Least Squares } \\
\text { Date: 07/08/19 Time: } 20: 23 \\
\text { Sample (adjusted): } 19862017 \\
\text { Included observations: } 32 \text { after adjustments }\end{array}$} & \\
\hline Variable & coefficient & standard error & t-statistic & prob. \\
\hline $\begin{array}{l}\mathrm{D}(\operatorname{LOGEX}(-1) \\
\mathrm{D}(\operatorname{LOGEX}(-1), 2)\end{array}$ & $\begin{array}{l}1.757422 \\
0.307534\end{array}$ & $\begin{array}{l}0.283200 \\
0.172839\end{array}$ & $\begin{array}{l}-6.205590 \\
1.779307\end{array}$ & $\begin{array}{l}0.000 \\
0.0853\end{array}$ \\
\hline $\begin{array}{l}\text { R-squared } \\
\text { Adjusted R-squared } \\
\text { S.E. of regression } \\
\text { Sum squared resid } \\
\text { Log likelihood } \\
\text { Durbin-Watson stat }\end{array}$ & $\begin{array}{c}0.704300 \\
0.694444 \\
0.964738 \\
27.92159 \\
-43.22466 \\
1.986863\end{array}$ & $\begin{array}{l}\text { Mean depe } \\
\text { S.D. depen } \\
\text { Akaike info } \\
\text { Schwarz cri } \\
\text { Hannan-Qu }\end{array}$ & $\begin{array}{lc}\text { ar } & 0.0061 \\
\text { ar } & 1.7452 \\
\text { on } & 2.826 \\
& 2.9181 \\
\text { er. } & 2.856\end{array}$ & \\
\hline
\end{tabular}

Table 1(b): ADF test on log openness, at first difference with no intercept and trend

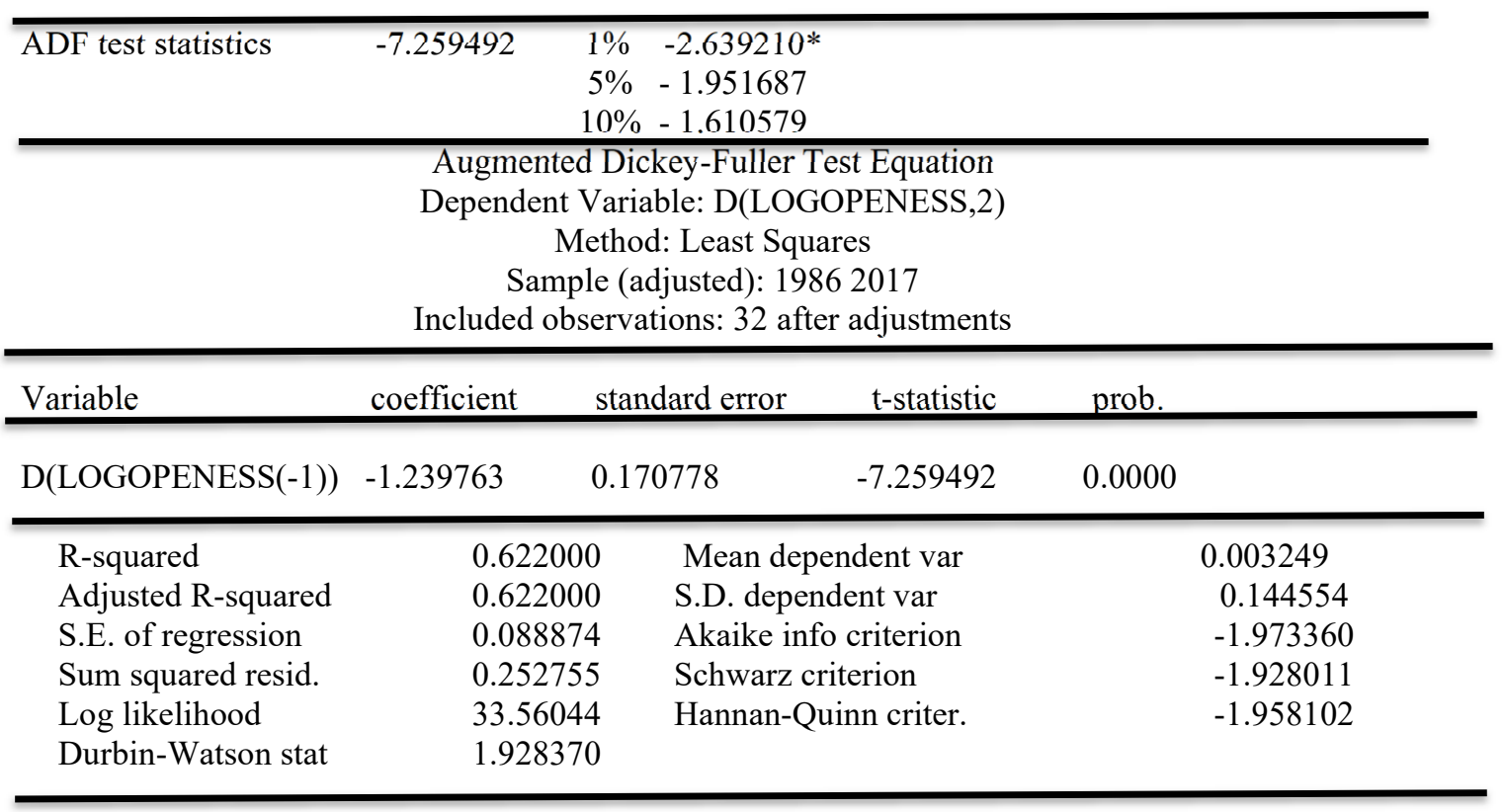


Table 1(c): ADF test on $\log \boldsymbol{g} \boldsymbol{d p}$, at first difference with no intercept and trend

\begin{tabular}{|c|c|c|c|c|c|}
\hline \multirow[t]{2}{*}{ ADF test statistics } & \multirow[t]{2}{*}{-2.835826} & \multicolumn{3}{|c|}{$\begin{array}{cc}1 \% & -2.639210^{*} \\
5 \% & -1.951687 \\
10 \% & -1.610579 \\
\end{array}$} & \\
\hline & & \multicolumn{3}{|c|}{$\begin{array}{c}\text { Augmented Dickey-Fuller Test Equation } \\
\text { Dependent Variable: D(LOGGDP,2) } \\
\text { Method: Least Squares } \\
\text { Date: 07/08/19 Time: } 20: 23 \\
\text { Sample (adjusted): } 19862017 \\
\text { Included observations: } 32 \text { after adjustments }\end{array}$} & \\
\hline Variable & & Coefficient & Std. Error & t-Statistic & Prob. \\
\hline $\mathrm{D}(\operatorname{LOGGDP}(-1))$ & & -0.405658 & 0.143048 & -2.835826 & 0.0079 \\
\hline $\begin{array}{l}\text { R-squared } \\
\text { Adjusted R-squared } \\
\text { S.E. of regression } \\
\text { Sum squared resid } \\
\text { Log likelihood } \\
\text { Durbin-Watson stat }\end{array}$ & & $\begin{array}{l}0.199906 \\
0.199906 \\
0.053291 \\
0.090877 \\
50.43848 \\
1.896703\end{array}$ & $\begin{array}{l}\text { Mean depeno } \\
\text { S.D. depende } \\
\text { Akaike info } \\
\text { Schwarz crit } \\
\text { Hannan-Quir }\end{array}$ & $\begin{array}{l}\text { var } \\
\text { ar } \\
\text { rion } \\
\text { n } \\
\text { riter. }\end{array}$ & $\begin{array}{r}0.002002 \\
0.059577 \\
-2.996272 \\
-2.950923 \\
-2.981013\end{array}$ \\
\hline
\end{tabular}

Table 1 (d): ADF test on $\log$ cap, at first difference with no intercept and trend

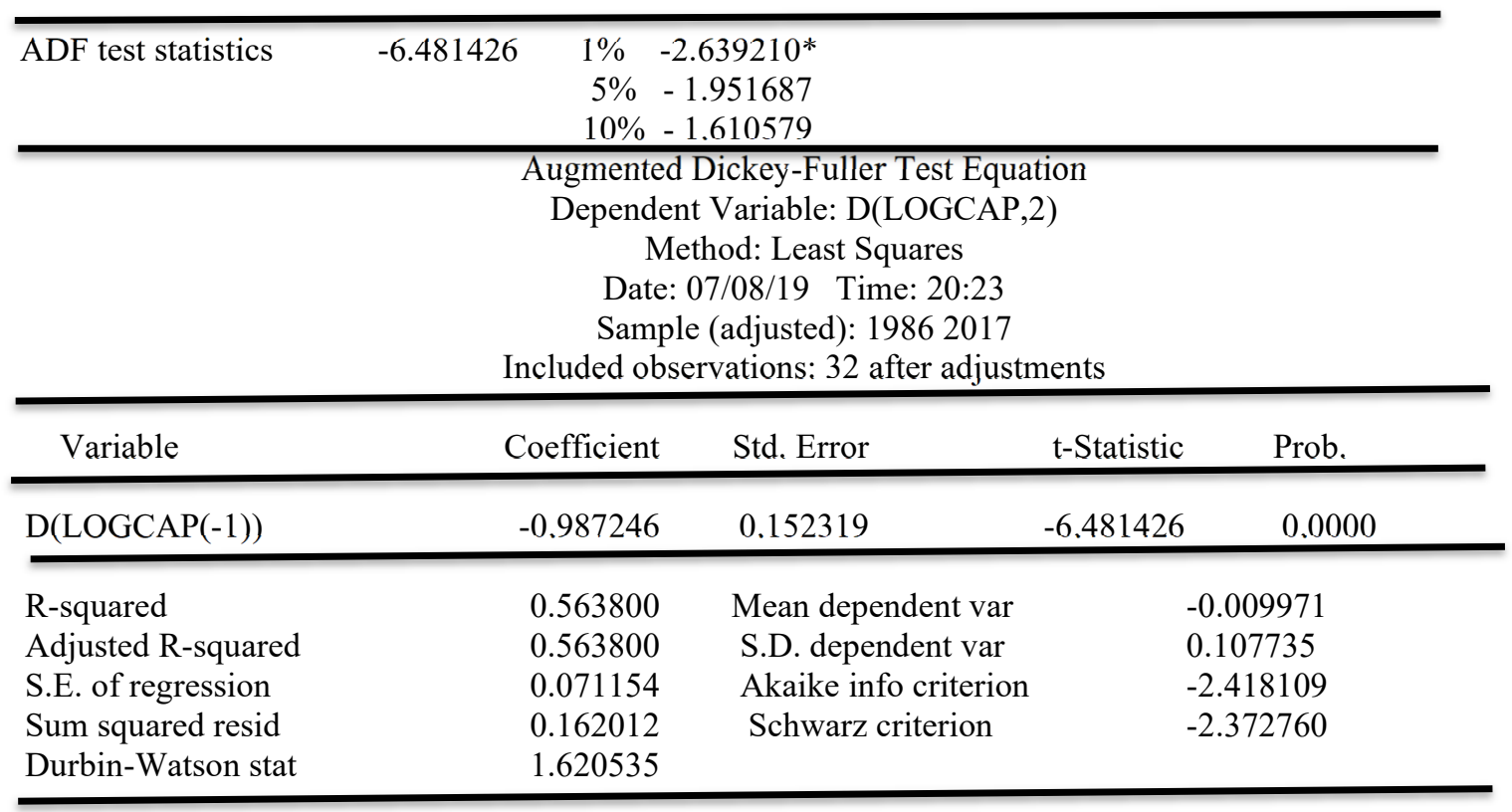


Table 1(e): ADF test on $\log p w$, at first difference with no intercept and trend

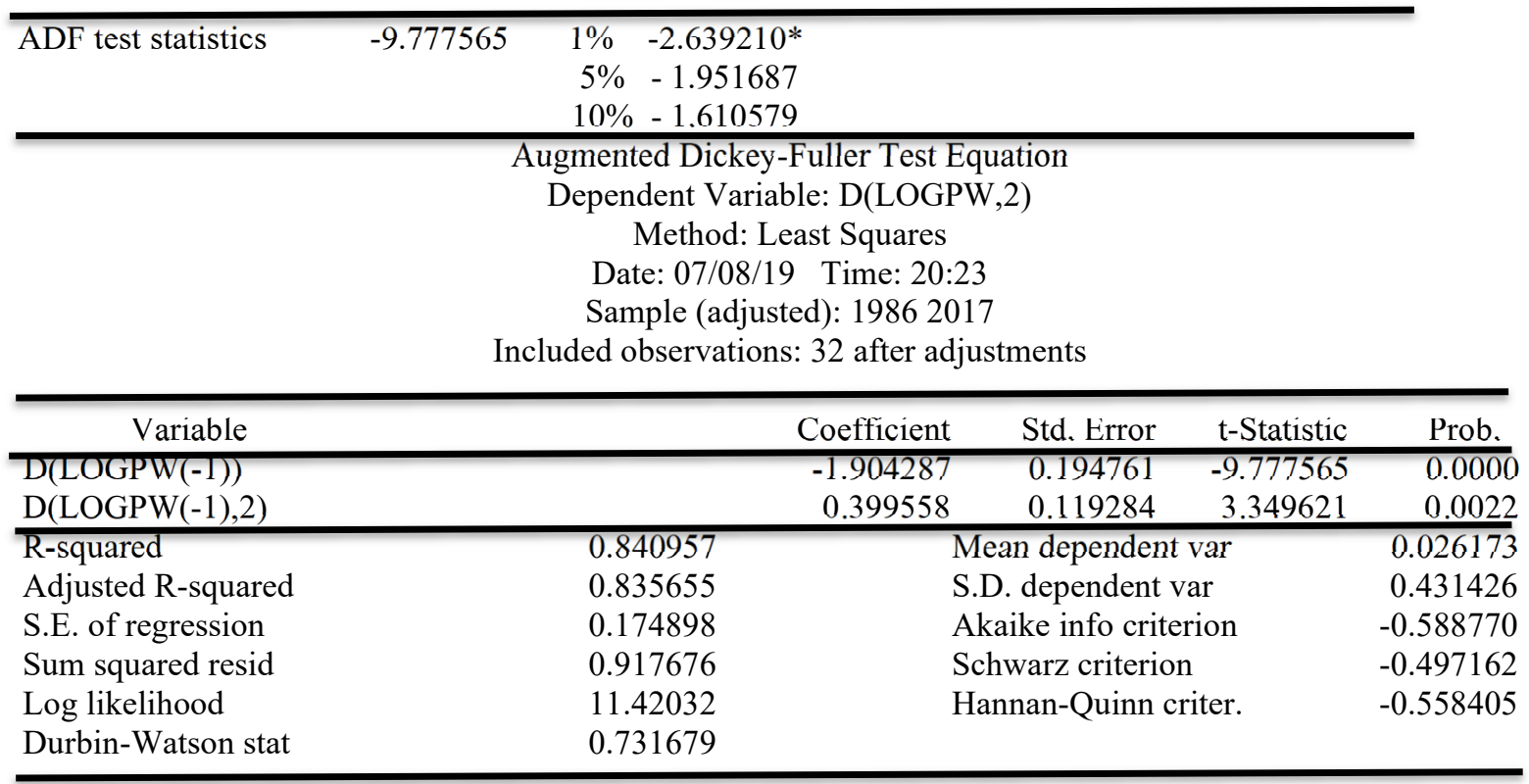

Table 2: Johannsen co-integration test on log dv, log openness, log cap, log ggdp and log pw

Sample (adjusted): 19852017

Included observations: 33 after adjustments

Trend assumption: Linear deterministic trend

Series: LOGEX LOGOPENESS LOGPW LOGGDP LOGCAP

Unrestricted Co-integration Rank Test (Trace)

Lags interval (in first differences): 1 to 1

\begin{tabular}{ccccc}
\hline $\begin{array}{c}\text { Hypothesized } \\
\text { No. of CE(s) }\end{array}$ & Eigenvalue & $\begin{array}{c}\text { Trace } \\
\text { Statistic }\end{array}$ & $\begin{array}{c}0.05 \\
\text { Critical Value }\end{array}$ & Prob.** \\
\hline None ${ }^{*}$ & 0.726708 & 86.88316 & 69.81889 & 0.0012 \\
At most 1 & 0.548412 & 44.07513 & 47.85613 & 0.1084 \\
At most 2 & 0.301251 & 17.84064 & 29.79707 & 0.5779 \\
At most 3 & 0.152422 & 6.011341 & 15.49471 & 0.6942 \\
At most 4 & 0.016649 & 0.554047 & 3.841466 & 0.4567 \\
\hline
\end{tabular}

Trace test indicates 1 co-integrating eqn(s) at the 0.05 level

* denotes rejection of the hypothesis at the 0.05 level

**MacKinnon-Haug-Michelis (1999) p-values

Unrestricted Co integration Rank Test (Maximum Eigenvalue)

\begin{tabular}{ccccc}
\hline $\begin{array}{c}\text { Hypothesized } \\
\text { No. of CE(s) }\end{array}$ & Eigenvalue & $\begin{array}{c}\text { Max-Eigen } \\
\text { Statistic }\end{array}$ & $\begin{array}{c}0.05 \\
\text { Critical Value }\end{array}$ & Prob.** \\
\hline None * & 0.726708 & 42.80803 & 33.87687 & 0.0033 \\
At most 1 & 0.548412 & 26.23449 & 27.58434 & 0.0736 \\
At most 2 & 0.301251 & 11.82930 & 21.13162 & 0.5646 \\
At most 3 & 0.152422 & 5.457294 & 14.26460 & 0.6834 \\
At most 4 & 0.016649 & 0.554047 & 3.841466 & 0.4567 \\
\hline
\end{tabular}

Max-eigenvalue test indicates 1 co-integrating eqn(s) at the 0.05 level

$*$ denotes rejection of the hypothesis at the 0.05 level

**MacKinnon-Haug-Michelis (1999) p-values 
Unrestricted Co-integrating Coefficients (normalized by $b^{\prime * S} 11^{*} \mathrm{~b}=\mathrm{I}$ ):

\begin{tabular}{ccccc}
\hline LOGDV & LOGOPENESS & LOGPW & LOGRGDP & LOGCAP \\
1.387852 & -8.179314 & 8.197022 & -7.895675 & 9.580651 \\
0.639301 & 8.933977 & -1.017689 & -0.719302 & -2.629292 \\
-0.268610 & 8.210305 & 2.829973 & -0.821710 & -7.465797 \\
0.115488 & 7.185927 & -1.909313 & 4.947201 & -13.67973 \\
0.426850 & 2.067378 & 0.304911 & -3.691522 & -3.338427 \\
\hline
\end{tabular}

Unrestricted Adjustment Coefficients (alpha):

\begin{tabular}{crrrrr}
\hline D(LOGDV) & -0.549781 & -0.191681 & 0.217471 & -0.188100 & -0.008588 \\
D(LOGOPENESS) & -0.014698 & 0.004027 & 0.028272 & 0.006989 & 0.005524 \\
D(LOGPW) & -0.129030 & 0.050787 & -0.061170 & 0.017158 & 0.004849 \\
D(LOGRGDP) & 0.007501 & 0.019905 & -0.008955 & -0.008368 & -0.000129 \\
D(LOGCAP) & -0.009324 & 0.015365 & 0.023732 & 0.015247 & -0.000994 \\
\hline
\end{tabular}

1 Co-integrating Equation(s):

$$
\text { Log } \quad 143.0551
$$

likelihood

Normalized co integrating coefficients (standard error in parentheses)

\begin{tabular}{ccccr}
\hline LOGDV & LOGOPENESS & LOGPW & LOGRGDP & LOGCAP \\
1.000000 & -5.893504 & 5.906263 & -5.689132 & 6.903220 \\
& $(1.38539)$ & $(0.56496)$ & $(0.57763)$ & $(1.52432)$ \\
Adjustment coefficients & $($ standard error in parentheses) & & \\
D(LOGDV) & -0.763015 & & \\
& $(0.20625)$ & & \\
D(LOGOPENESS) & -0.020399 & & \\
D(LOGPW) & $(0.01909)$ & & \\
& -0.179074 & & \\
D(LOGRGDP) & $(0.04450)$ & & \\
D(LOGCAP) & 0.010411 & & \\
& $(0.01044)$ & & \\
\end{tabular}


2 Cointegrating Equation(s):

$$
\log
$$

156.1723

$$
\text { likelihood }
$$

Normalized cointegrating coefficients (standard error in parentheses)

\begin{tabular}{lcccc}
\hline LOGDV & LOGOPENESS & LOGPW & LOGRGDP & \multicolumn{1}{c}{ LOGCAP } \\
1.000000 & 0.000000 & 3.682079 & -4.335307 & 3.635534 \\
& & $(0.61032)$ & $(0.60218)$ & $(0.90494)$ \\
0.000000 & \multirow{2}{*}{1.000000} & -0.377396 & 0.229715 & -0.554456 \\
& & $(0.08726)$ & $(0.08610)$ & $(0.12939)$ \\
\hline
\end{tabular}

Adjustment coefficients (standard error in parentheses)

\begin{tabular}{ccc} 
D(LOGDV) & -0.885557 & 2.784359 \\
& $(0.21970)$ & $(1.74154)$ \\
D(LOGOPENESS) & -0.017825 & 0.156197 \\
& $(0.02098)$ & $(0.16630)$ \\
D(LOGPW) & -0.146606 & 1.509106 \\
& $(0.04657)$ & $(0.36915)$ \\
D(LOGRGDP) & 0.023136 & 0.116476 \\
& $(0.00982)$ & $(0.07785)$ \\
D(LOGCAP) & -0.003118 & 0.213539 \\
& $(0.01818)$ & $(0.14413)$ \\
\hline
\end{tabular}

3 Cointegrating Equation(s):

Log $\quad 162.0870$

likelihood

Normalized cointegrating coefficients (standard error in parentheses)

\begin{tabular}{ccccc} 
LOGDV & LOGOPENESS & LOGPW & LOGRGDP & LOGCAP \\
\hline \multirow{2}{*}{1.000000} & 0.000000 & 0.000000 & $\begin{array}{r}-2.274187 \\
(0.94919)\end{array}$ & $\begin{array}{r}4.666566 \\
(1.83930)\end{array}$ \\
0.000000 & 1.000000 & 0.000000 & 0.018460 & -0.660132 \\
& & & $(0.08459)$ & $(0.16391)$ \\
0.000000 & 0.000000 & 1.000000 & -0.559771 & -0.280014 \\
& & & $(0.20791)$ & $(0.40287)$
\end{tabular}

\begin{tabular}{cccc}
\hline & & & \\
D(LOGDV) & -0.943972 & 4.569861 & -3.696059 \\
& $(0.21302)$ & $(2.00922)$ & $(1.19887)$ \\
D(LOGOPENESS $)$ & -0.025419 & 0.388318 & -0.044572 \\
& $(0.01949)$ & $(0.18379)$ & $(0.10966)$ \\
D(LOGPW) & -0.130175 & 1.006885 & -1.282452 \\
& $(0.04347)$ & $(0.40996)$ & $(0.24462)$ \\
D(LOGRGDP) & 0.025541 & 0.042954 & 0.015888 \\
D(LOGCAP) & $(0.00959)$ & $(0.09047)$ & $(0.05398)$ \\
& -0.009493 & 0.408386 & -0.024908 \\
& $(0.01699)$ & $(0.16025)$ & $(0.09562)$ \\
\hline
\end{tabular}


4 Cointegrating Equation(s):

Log
likelihood

Normalized cointegrating coefficients (standard error in parentheses)

\begin{tabular}{ccccc}
\hline LOGDV & LOGOPENESS & LOGPW & LOGRGDP & LOGCAP \\
1.000000 & 0.000000 & 0.000000 & 0.000000 & -1.012433 \\
& & & & $(2.34891)$ \\
0.000000 & 1.000000 & 0.000000 & 0.000000 & -0.614035 \\
& & & $(0.13868)$ \\
0.000000 & 0.000000 & 1.000000 & 0.000000 & -1.677849 \\
& & & & $(0.59695)$ \\
0.000000 & 0.000000 & 0.000000 & 1.000000 & -2.497156 \\
& & & & $(0.86138)$ \\
\hline Adjustment coefficients (standard error in parentheses) & & \\
\hline D(LOGDV) & -0.965695 & 3.218189 & -3.336917 & 3.369503 \\
& $(0.20576)$ & $(2.15611)$ & $(1.18208)$ & $(1.24076)$ \\
D(LOGOPENESS) & -0.024612 & 0.438537 & -0.057915 & 0.124500 \\
D(LOGPW) & $(0.01942)$ & $(0.20353)$ & $(0.11159)$ & $(0.11712)$ \\
& & 1.130182 & -1.315213 & 1.117393 \\
D(LOGRGDP) & $(0.04327)$ & $(0.45342)$ & $(0.24858)$ & $(0.26093)$ \\
D(LOGCAP) & 0.024575 & -0.017176 & 0.031865 & -0.107583 \\
& $(0.00927)$ & $(0.09717)$ & $(0.05327)$ & $(0.05592)$ \\
& -0.007732 & 0.517951 & -0.054020 & 0.118500 \\
& $(0.01639)$ & $(0.17174)$ & $(0.09416)$ & $(0.09883)$ \\
& & & &
\end{tabular}

Table 4: Estimation result using VECM

Dependent Variable: D(LOGEX)

Method: Least Squares

Date: 07/13/19 Time: 21:56

Sample (adjusted): 19852017

Included observations: 33 after adjustments

$\mathrm{D}($ LOGEX $)=\mathrm{C}(1) *($ LOGEX $(-1)-5.68913177445 *$ LOGRGDP $(-1)$ -

$5.89350444465 *$ LOGOPENESS(-1) + 5.90626346556*LOGPW $(-1)+$ $6.90322022951 * \operatorname{LOGCAP}(-1)+40.066530169)+\mathrm{C}(2) * \mathrm{D}(\operatorname{LOGDV}(-1))$

$+\mathrm{C}(3) * \mathrm{D}(\operatorname{LOGRGDP}(-1))+\mathrm{C}(4) * \mathrm{D}(\operatorname{LOGOPENESS}(-1))+\mathrm{C}(5)$

$* \mathrm{D}(\operatorname{LOGPW}(-1))+\mathrm{C}(6) * \mathrm{D}(\operatorname{LOGCAP}(-1))+\mathrm{C}(7)$

\begin{tabular}{ccccc}
\hline & Coefficient & Std. Error & t-Statistic & Prob. \\
\hline C(1) & -0.763015 & 0.206250 & -3.699462 & 0.0010 \\
C(2) & 0.009956 & 0.174063 & 0.057196 & 0.9548 \\
C(3) & 4.768950 & 3.360384 & 1.419168 & 0.1677 \\
C(4) & -0.886590 & 2.329590 & -0.380578 & 0.7066 \\
C(5) & 1.977354 & 0.809656 & 2.442217 & 0.0217 \\
C(6) & 5.785447 & 2.403833 & 2.406759 & 0.0235 \\
C(7) & -0.311384 & 0.191031 & -1.630016 & 0.1152 \\
& & & & -0.043507 \\
R-squared & 0.459820 & Mean dependent var & 1.047010 \\
Adjusted R-squared & 0.335164 & S.D. dependent var & 2.707371 \\
S.E. of regression & 0.853706 & Akaike info criterion & 3.024812 \\
Sum squared resid & 18.94914 & Schwarz criterion & 2.814180 \\
Log likelihood & -37.67161 & Hannan-Quinn criter. & 2.014614 \\
F-statistic & 3.688689 & Durbin-Watson stat & \\
Prob(F-statistic) & 0.008742 & & \\
\hline
\end{tabular}


Table 5: ADF test on $\boldsymbol{E C T}$ at level with no intercept and trend

\begin{tabular}{|c|c|c|c|c|}
\hline ADF test statistics & -8.930066 & $\begin{array}{cc}1 \% & -2.639210^{*} \\
5 \% & -1.951687 \\
10 \% & -1.610579\end{array}$ & & \\
\hline \multicolumn{5}{|c|}{$\begin{array}{c}\text { Augmented Dickey-Fuller Test Equation } \\
\text { Dependent Variable: D(ECT,2) } \\
\text { Method: Least Squares } \\
\text { Date: 07/08/19 Time: } 20: 23 \\
\text { Sample (adjusted): } 19862017 \\
\text { Included observations: } 33 \text { after adjustments }\end{array}$} \\
\hline Variable & coefficient & standard error & t-statistic & prob. \\
\hline D(LOGEX $(-1)$ & -1.427077 & 0.159806 & -68.930066 & 0.000 \\
\hline $\begin{array}{l}\text { R-squared } \\
\text { Adjusted R-squared } \\
\text { S.E. of regression } \\
\text { Sum squared resid } \\
\text { Log likelihood } \\
\text { Durbin-Watson stat }\end{array}$ & $\begin{array}{l}0.713606 \\
0 . .713606 \\
0.119152 \\
0.454308 \\
23.88557 \\
1.896906\end{array}$ & $\begin{array}{l}\text { Mean dependent var } \\
\text { S.D. dependent var } \\
\text { Akaike info criterion } \\
\text { Schwarz criterion } \\
\text { Hannan-Quinn criter. }\end{array}$ & $\begin{array}{l}\text { r } \\
00002258 \\
0.222648 \\
-1.387004 \\
-1.341655 \\
-1.371746\end{array}$ & \\
\hline
\end{tabular}

Table 5: auto correlation, normality and hetroscedacity test

Breusch-Godfrey Serial Correlation LM Test:

Null hypothesis: No serial correlation at up to 2 lags

\begin{tabular}{llll}
\hline \hline F-statistic & 0.467894 & Prob. F(2,25) & 0.6317 \\
Obs*R-squared & 1.190673 & Prob. Chi-Square(2) & 0.5514 \\
\hline \hline
\end{tabular}

Heteroskedasticity Test: Breusch-Pagan-Godfrey

Null hypothesis: Homoskedasticity

\begin{tabular}{llll}
\hline \hline F-statistic & 1.060743 & Prob. F(8,24) & 0.4215 \\
Obs*R-squared & 8.620223 & Prob. Chi-Square(8) & 0.3753 \\
Scaled explained SS & 4.617264 & Prob. Chi-Square(8) & 0.7976
\end{tabular}

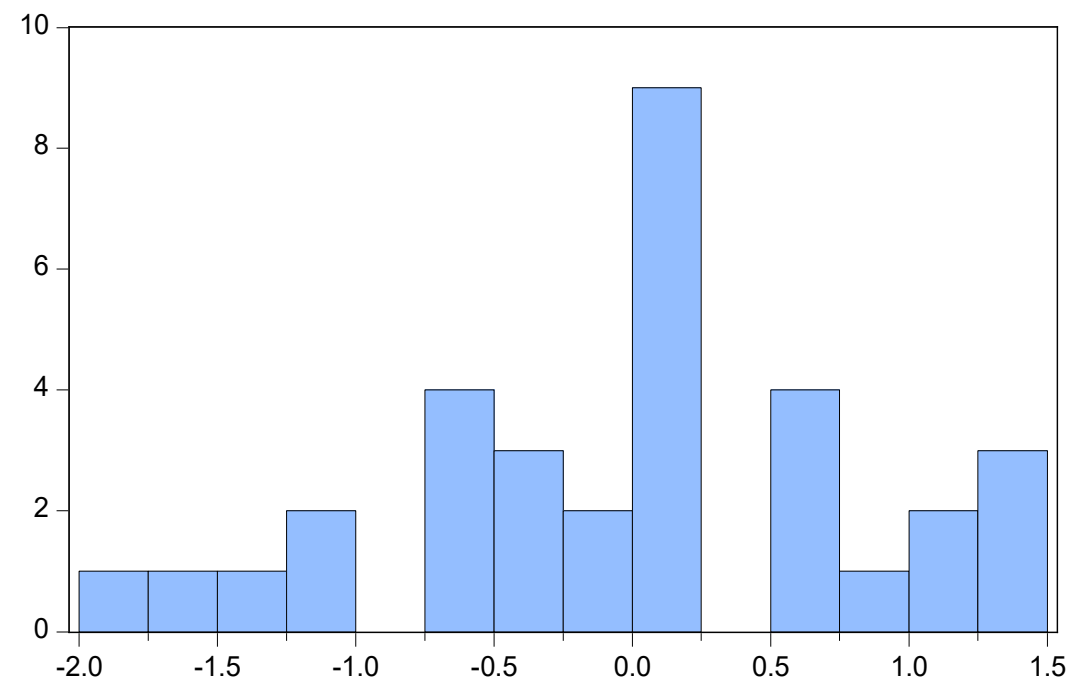

